\title{
Eliza Kącka: Ciało mitu. Piłsudski Brunona Schulza
}

\section{1. w którym objawia się Historia}

We Wspomnieniach polskich czytamy: „W dzień imienin pani Zofii Nałkowskiej zawsze nawiedzały jej mieszkanie na Marszałkowskiej nieopodal placu Unii Lubelskiej całe tłumy gości. W roku 1935 na ten dzień świętej Zofii (a może na któryś z sąsiednich dni) ludu nawaliło się co niemiara [...]. Przyjęcie dochodziło do swego apogeum, gdy nagle... nawiedzanie Nałkowskiej coś się stało. Nie mogłem uchwycić w pierwszej chwili, na czym polegała nagła, a tak wyraźna, zmiana, naokoło mnie, przy bufecie, ludzie rozmawiali z kieliszkami, talerzykami w dłoni - a jednak w ogólnym szumie i gwarze nastąpiło jakby załamanie.

Naraz widzę, że z salonu wychodzi któraś z pisarek - może Szelburg Zarębina, może Melcer-Rutkowska - zapłakana. Łzy ściekały jej po policzkach. Co to było? Czyżby ją kto obraził?

Gdy wtem jeszcze dwie kobiety wychodzą głośno szlochając, a za nimi kilku mężczyzn z wyrazem twarzy dramatycznym. I na oko cisza zaczęła wypierać hałasy przyjęcia. Znów kilka osób ruszyło do wyjścia, nakładano pośpiesznie okrycia.

Na koniec zrozumiałem: Piłsudski. Już od kilku dni wiadomo było, że stan jego jest bardzo niepokojący...

Teraz już wszyscy wychodzili, żegnano się po cichu, pośpiesznie... A że Belweder był niedaleko, goście pani Zofii biegli w tamtą stronę. Ja też z Adolfem Rudnickim i kilkoma innymi. Zaledwie dwa czy trzy samochody stały przed pałacem, a na ulicy przed bramą wjazdową tylko garstka ludzi wyczekiwała - wiadomość jeszcze nie obiegła miasta. My należeliśmy do najwcześniej poinformowanych. Biały fronton pałacu, doskonale widoczny w świetle latarń, był tajemniczy i cichy...

Naraz sznur Cadillaców jął wjeżdżać na dziedziniec - to był rząd z premierem Składkowskim na czele, po raz ostatni meldujący się u Marszałka"1. 
bieg do Marszałka

wizytator jako zmora

Ten opisany przez Gombrowicza we Wspomnieniach polskich bieg z Marszałkowskiej 4 do Marszałka, ów jedyny marsz pod Belweder godny pióra Żeromskiego, który dokonał się rzeczywiście, jest punktem zerowym narodzin legendy ${ }^{2}$. O tej legendzie właśnie pisze w swoim pożegnalnym szkicu Bruno Schulz. Chciałoby się wierzyć, że był tam wtedy, u boku Gombrowicza i innych wymienionych i niewymienionych pisarzy, i nie jest to w końcu całkiem niemożliwe. Na drodze legendy stają, jak zwykle, szczegóły. Zgon Marszałka nastąpił w niedzielę 12 maja, imieniny Zofii przypadają zaś na 15 maja. Ale przecież mogła Nałkowska przenieść swoje imieniny wcześniej, jak to się nieraz robiło i robi. Nowo założone kalendarium Brunona Schulza lokalizuje w maju jedno jedyne zdarzenie: list, jaki wysłał Schulz do Tadeusza i Zofii Brezów z Drohobycza z datą 13 maja, a więc nazajutrz. Co prawda, można by przypuścić, że Schulz, zdruzgotany wydarzeniem, przemieścił się błyskawicznie do swego rodzinnego miasta, tak jak przed rokiem i miesiącem pojawił się w Warszawie zaledwie na kilka godzin, by wręczyć Nałkowskiej swój manuskrypt Sklepów cynamonowych. Niestety, rzut oka w list Schulza ucina te gdybania. Już trzecie zdanie tegoż powiada bowiem: „Wizytator usadowił się w Drohobyczu i ciąży nam jak zmora”. Pisarz tkwił więc w szkole pod bacznym okiem, któremu nie zdołałby się wymknąć $c^{3}$.

Pokusę spekulacji wokół tego, czy Bruno Schulz był pod Belwederem, miał również wydawca tekstu Powstaja legendy, Stanisław Rosiek. Zanotował: „Niewielka zmiana punktu widzenia, niewielki obrót i oto jest: Schulz stoi pośród żałobników publicznie rozpaczających po śmierci Pierwszego Marszałka Polski"4.

Tak, Rosiek też wie, że autor Sanatorium pod Klepsydra przebywał tego dnia w Drohobyczu. Duchowo jednak niewątpliwie stał owego wieczora przed godziną dziewiątą pod Belwederem, $\mathrm{w}$ chronotopie legendy.

\section{2. w którym nadchodzi Wielkość}

W trybie legendotwórczym przyjęłam, że Bruno Schulz znajdował się tej nocy pod Belwederem. Otóż nie ulega dziś chyba wątpliwości, że Witold Gombrowicz, Bruno Schulz - a może i Witkacy - potrafili w wielu sprawach zrozumieć się niemal bez słowa. Wiemy skądinąd, jak na scenę pod Belwederem zareagował Gombrowicz: „Spojrzałem ze złością na

2 Właśnie z uwagi na ten czynnik Gombrowicz zdobył się na reakcję, o której dalej.

3 B. Schulz, Dzieła zebrane, t. 5: Księga listów, zebrał i przygotował do druku J. Ficowski, uzup. S. Danecki, Gdańsk 2016, s. 54.

4 S. Rosiek, Mitjako wódz, w: B. Schulz, Powstajq legendy. Trzy szkice wokółPiłsudskiego, Kraków 1993, s. 3. 
blade oblicza kilku kolegów pisarzy i powiedziałem głośno, przed siebie: - Jakie ładne samochody!"5.

Gombrowicz bał się narodzin legendy, bał się jej siły destrukcyjnej i miał dystans do jej populistycznej osnowy. Przypuszczać można, że na jego miejscu Schulz ironizowałby podobnie. Zresztą - czemu tylko przypuszczać? Otwórzmy ostatni rozdział opowieści Wiosna, gdzie narrator zwraca się do swej gwardii w wysoce dwuznacznym stylu: „Panowie [...] po tym, co się stało, żadne panoptikum was nie przyjmie, tym bardziej, że konkurencja jest wielka. Będziecie musieli zrezygnować nieco $\mathrm{z}$ waszych ambicyj. Staniecie się za to wolnymi ludźmi, a wiem, że umiecie to cenić. Ponieważ nie nauczono was niestety żadnych praktycznych zawodów, was, predestynowanych do czystej reprezentacji, ufundował mój przyjaciel kwotę, wystarczającą na zakupienie dwunastu katarynek ze Szwarcwaldu. Rozejdziecie się po świecie grając ludowi ku pokrzepieniu serc. Dobór aryj do was należy. Po cóż tracić wiele słów - nie jesteście całkiem prawdziwymi [...] Napoleonami. Jesteście nimi, żeby tak rzec - tylko w braku lepszych"6.

I to jest wyrażona przez Brunona Schulza ocena rządu pułkowników. Co istotne, szkic Powstają legendy opublikowany został w 1935 roku w 22, specjalnym, numerze „Tygodnika Ilustrowanego”. Wydanie z 2 czerwca przygotowywano więc, być może, równocześnie z kończeniem przez Schulza prac nad Wiosna, co rzuca osobliwe światło zarówno na wątki polityczne opowieści, jak i na estetyzację legendy Piłsudskiego.

Wiadomo, jak już za życia mitologizowano Marszałka - nie do końca żartem jego wielbiciel Tuwim, podobnie jak Schulz, przedstawiał wodza jako Zeusa na szczycie Olimpu w obłokach7 ${ }^{7}$ Obaj uwielbiali uwielbiać. Esencję tej atmosfery zawiera zresztą o ponad dekadę wcześniejsza rozmowa z Marszałkiem, którą zanotował przebywający na emigracji w Warszawie pisarz rosyjski Dymitr Mereżkowski, wielka podówczas sława, a którą w formie broszury rozpowszechniano w armii. Zobaczmy, w jakim tonie wprowadza się tu, ujmowanego czysto po Carlyleowsku, bohatera: „Niemasz na ziemi nic godniejszego czci, jak odblask lica Bożego w obliczu człowieczem, w Bohaterze. Bohater wciąż jeszcze, jak ongi, tak samo w dniu dzisiejszym jest niewzruszonem objawieniem Bóstwa, Teofanją. Gdy wszedł on do komnaty, "wionęło» na mnie "wianie cichego wiatru», o którym mowa jest w Księdze Królestw; odrazu uczułem: tak, to - On,

5 W. Gombrowicz, op. cit., s. 128.

6 B. Schulz, Opowiadania. Wybór esejów i listów, oprac. J. Jarzębski, Wrocław 1989, s. 209-210.

7 Na przykład w wierszu Z Iliady, ogłoszonym w "Cyruliku Warszawskim” (1930) i przedrukowanym w Jarmarku rymów (1934). Oto jeszcze jedna zbieżność postaw Tuwima i Schulza - zapomniał o niej Jan Gondowicz w szkicu Tuwimowskie cynamony z tomu Trans-Autentyk. Nie-czyste formy Brunona Schulza (Warszawa 2014, s. 211 i n.). 
On,

Bohater...

...i mundury

Bohater ens realissimum, «byt najistotniejszy», jak wyraził się Nietzsche o Napoleonie [...]. W pałacu Belwederskim - prosta, cicha komnata; proste, ciche niebo w otwartem oknie, mglistoszare, nad mglisto-zieloną gęstwą Łazienek. I on - cichy, prosty, jak niebo"8.

Zauważmy, jak w gruncie rzeczy blisko tej dostojnej ciszy do znanej frazy Lechonia: „A on mówić nie może, mundur na nim szary”. Istnieją jednak świadectwa, bynajmniej niepozbawione szacunku, wolne od hagiografii. Za jeden $\mathrm{z}$ takich dokumentów, który przywraca rzeczom realne proporcje, uznać można list, bardzo zresztą sceptycznego co do rządów przedmajowych, Jerzego Stempowskiego do matki: „Domek Dziadka, w kształcie bardzo skromnego dworku z gankiem o dwu kolumienkach, wznosi się w żałościwie rzadkiej sośninie, bez parkanu, niby na samym środku pastwiska wszechpolskiego. [...] W końcu długiej galerii pozbawionej jakiegokolwiek mebla Dziadek siedział w niskim pokoju, równie pustym, i przyjmował życzenia. Siedział na krześle $\mathrm{w}$ wytartym mundurze marszałka, $\mathrm{z}$ dobrą miną, ale jak gdyby trochę zmęczoną [...]. Tego dnia musiało przejść przez Sulejówek około tysiąca osób, które prawie wszystkie były mi znajome [...]. Była to szczerozłota kolekcja zawiedzionych i niepotrzebnych, nigdzie już nie przyrosłych do rzeczywistości. [...] Byli to przyobleczeni w mundury inteligenci, zgarbieni w swoich okularach, z prawym ramieniem wyższym od piśmiennictwa, niegdyś liworucyjnego, potem pułkowego, zawsze romantycznie naderwanego i pozytywistycznie niezgrabnego, emigracyjno-komitetowo-kawiarniano-krakowskostrzelecko-warszawskiego. [...] Wszystko to należy już do legendy, która rozwiała się i od której, przecierając oczy, odwraca się nowa, szara, wulgarna i twarda rzeczywistość"10.

Opisane tu imieniny celebrowano niespełna dwa lata przed dojściem tego towarzystwa do władzy.

Problem wielkiego człowieka, przewodnika narodu, jaki wedle wszelkich reguł sztuki wyłania się z portretu danego nam przez Mereżkowskiego w szkicu Józef Piłsudski, zawiera w sobie tradycyjnie dwa składniki: pierwszym z nich jest w i el k o ść, drugim - zamysł Opatrzności. Nie przypadkiem jednym z najbardziej znanych zdań Piłsudskiego było pytanie przewijające się niby refren we wspaniałym odczycie wygłoszonym w styczniu 1924 roku w Warszawie: „Wielkości, gdzie twoje imię?”"11. I w klechdzie o powstaniu styczniowym niełatwo mu przyszło je znaleźć.

8 D. Mereżkowski, Józef Piłsudski, przeł. W[acław] R[ogowicz], Warszawa 1920, s. 6-7.

9 J. Lechoń, Piłsudski, w: idem, Karmazynowy poemat, Warszawa 1922, s. 50.

10 J. Stempowski, List z 26 marca 1924, w: idem, Listy, wyb. i red. B. Toruńczyk, Warszawa 2000, s. 152-153.

11 J. Piłsudski, Rok 1863, Warszawa 1924, s. 33 i n. 
Ale nie sam Piłsudski kładł nacisk na opatrznościowo-heroiczny wymiar życia w legendzie. W roku 1909 wyszedł w Krakowie tom studiów Ralpha Waldo Emersona Przedstawiciele ludzkości, książka, którą - dało się to sprawdzić - Piłsudski i Schulz mieli w ręku. I wyczytać tam mogli: „Potrzebny był taki człowiek jak Napoleon, więc taki się też urodził; człowiek z kamienia i żelaza, mogący szesnaście lub siedemnaście godzin z rzędu spać na koniu, przez wiele dni poprzestawać na dorywczym posiłku i spoczynku, w walce dosięgać wroga skokiem tygrysa; człowiek niekrępowany przytem żadnymi wyrzutami sumienia; stanowczy, wytrwały, samolubny, mądry, nie dający się zmylić lub sprowadzić z drogi ani pretensjami innych, ani przesądami, ani też własną gorączkowością i zbytnim pośpiechem"12.

Jednakże śladem Cypriana Norwida, Stanisława Wyspiańskiego, Stefana Żeromskiego, a na koniec Stanisława Brzozowskiego ten właśnie wizerunek konfrontował Piłsudski z theatrum historycznym Polski. Nakreślony przezeń obraz Wielopolskiego, wielkiego człowieka osaczonego przez ludzi małych, którzy nie spoczną, aż jego wielkość unicestwią, okazał się więc rudymentem specyficznie polskiego romantyzmu politycznego. Owej dialektyce wielkości zawdzięcza szkic Schulza Powstają legendy uogólnioną konstatację: „Niewiara w wielkość wrodzona jest duchowi ludzkiemu. Jest w nas jakiś duch małości, który rozdrabnia, ryje, podgryza, kruszy, aż póki nie rozdrobi, nie rozniesie, nie przeryje skały wielkości. To jest nieustanna, żarliwa, podziemna praca małości”13. Wielkość wyraża się zatem nie poprzez nią samą, ale przez konfrontację z małością.

\section{3. w którym nastaje Legenda}

Uczeń Plutarcha, badacz wielkości, winien zadać sobie pytanie o jej źródła. I tu, jak można sądzić, w czasie, gdy pisał szkic o Piłsudskim, sprzymierzeńcem drohobyckiego nauczyciela, który corocznie na dzień św. Józefa wykonywać musiał do auli szkoły wcierkowy portret Marszałka, okazał się krytyk-demistyfikator, w którym rzadko widzi się jego inspiratora czy intelektualnego partnera. Aczkolwiek znali się osobiście od wczesnych lat dwudziestych. Rzec nawet można, iż Bruno Schulz i Karol Irzykowski znamionują biegunowe postawy galicyjskiego intelektualizmu.

Oto, co w 1915 roku pisał z okazji książki Juliusza Kadena-Bandrowskiego Piłsudczycy znany weredyk Irzykowski, zirytowany mgłą mistyczną, jaką wokół postaci Komendanta rozsnuwali jego legionowi akolici:

12 R.W. Emerson, Przedstawiciele ludzkości, przeł. M. Kreczowska, Kraków 2017, s. 183.

13 B. Schulz, Powstają legendy... s. 19-20. 
świecki euhemeryzm

„legenda jest procesem społeczno-kulturalnym i jako taki może powstawać nie tylko nieświadomie, lecz i świadomie. $\mathrm{W}$ ogóle wbrew różnym innym pozorom cały przełom kulturalny współczesnej epoki polega na tym, że okazuje się potrzeba świadomego stwarzania wielu rzeczy, a przynajmniej wywierania świadomie wpływu [...]. legenda wyprzedza czyny i fakty, towarzyszy im i następuje po nich. Filozof Sorel przywiązuje nawet do legendy - w przeciwieństwie do utopii - specjalne znaczenie, jako wizji przyszłej akcji, czegoś w rodzaju autosugestii rosnącej aż do wybuchu"14.

Oto spojrzenie wyzywająco trzeźwe i na gruncie polskim pionierskie. Najspokojniej w świecie krytyk prezentuje tu swoisty, by tak rzec, świecki euhemeryzm: legendy się robi, co więcej: robi się je rozmyślnie, mało tego: w ramach planowych zadań z zakresu reżyserii społecznej. Irzykowski przechodzi metodycznie od legend narzucanych ludowi przez poetów do błyskawicznego tempa wytwarzania ich w epoce pary i elektryczności, po czym stwierdza: „Proces legendyzacji odbywa się od chwili wybuchu wojny we wszystkich krajach. [...]. Ci, którzy dziś legendę stwarzają, liczą się na miliony"15. A jak w tym sytuować legendę Legionów?

"Jest ich naturalną potrzebą wytwarzać naokoło siebie własną legendę i upajać się jej nimbem. Można w tym widzieć literaturę, ale chyba podobnie, jak w wojnie niemieckiej chciano widzieć refleks idei Nietzschego [...]. Ostatecznie zawsze się naprzód coś myśli, mówi i pisze - i kto chce szykanować, może to nazwać «literaturą̧» - a potem się robi. [...] lud [...] może sobie potem przeciw temu zaprotestować, to jego rzecz. Legionom nie można jednak odmawiać prawa do tworzenia własnej legendy" ${ }^{16}$.

Niewątpliwie Irzykowski, pilny czytelnik prasy, bacznie śledził wynoszenie do legendowej rangi niemieckich „zbawców ojczyzny”, zwycięzców spod Tannenbergu - Hindenburga i Ludendorffa, a mogły też dojść doń odgłosy podobnych zabiegów w krajach ententy, obejmujące postaci zwycięzcy znad Marny - Joffre'a, organizatora brytyjskiego wysiłku militarnego - Kitchenera, oraz druzgocącego właśnie w tych dniach front galicyjski wielkiego księcia Mikołaja Mikołajewicza.

\section{4. w którym wyłania się Sprzeczność}

Kult jednostki ma swe zalety - inaczej mówiąc, chcę tu wyrazić przypuszczenie, że biblioteka szkolna drohobyckiego Gimnazjum im. Króla

14 K. Irzykowski, Z literatury legionowej, „Nowa Reforma” z 9 września 1915, w: idem, Pisma rozproszone, t. 1: 1897-1922, oprac. J. Bahr, Kraków 1998, s. 288.

15 Ibidem, s. 289.

16 Ibidem. 
Władysława Jagiełły od chwili, gdy przestało być ono Gimnazjum Realnym im. Cesarza Franciszka Józefa, jak każda inna gromadziła skrupulatnie prasówkę dotyczącą polskiego czynu niepodległościowego przedsięwzięcie niezbędne na potrzeby wszelkiego rodzaju rocznic. Jak najbardziej mógł się więc w owym zbiorze znaleźć, w roli wycinka edukacyjnego do biografii Komendanta, artykuł Irzykowskiego o Kadenie $\mathrm{z}$ „Nowej Reformy”. I po dwudziestu latach oddać usługi zgłębiającemu sekrety legend Schulzowi ${ }^{17}$. Wydaje się bowiem, że pisał on swoje studium $\mathrm{z}$ intencją jawnie wobec tez Irzykowskiego polemiczną. W mniej jawny sposób polemizuje jednak też z samym Marszałkiem.

Piłsudski bowiem aż nazbyt dobrze zdawał sobie sprawę z ciemnej strony legendowego dyskursu - jego opresyjności. Dość zajrzeć do odczytu z 1924 roku: „Wybrałem jako temat dwie główne legendy, te, które bodaj każdy człowiek musiał w siebie wchłaniać [...]. Działały tak sugestyjnie, a $\mathrm{z}$ a t e $\mathrm{m}$ [tryb wynikania! - E. K.] tak silnie skaziły przez swój fałsz nie tylko samą historię 63, ale i dusze ludzkie następnych po powstaniu pokoleń. Fałsz bowiem był tak jaskrawy, [...] że tylko trwożliwa niechęć do powtarzania eksperymentu dziejowego powstania wytłumaczyć zdoła ten dziwoląg psychiczny i myślowy. Dwie te bowiem legendy uczuciowo, psychicznie były sobie sprzeczne, natomiast skwapliwie były łączone ze sobą, jako czynnik wychowania tysięcy i tysięcy ludzi [...]. Z jednej strony więc prowadzono dziecko lub młodzieńca gdzieś w gęstwę lasu, by go wzruszyć zapomnianą mogiłą powstańca, by mu szeptem $\mathrm{w}$ ukryciu, nieraz z wyrzutem mówić, jak jest niepodobnym do swych ojców, gdy kłótnią przysparza domowi kłopotu [...]. A obok tego głośno i nieustannie stwierdzano słowem, wzruszaniem ramion, niecierpliwym lub niechętnym burknięciem wszystko, co było drugą legendą. Legendą głupoty, szaleństwa, często wręcz legendą zbrodni [...]. Osobiście tak często słyszałem te dwie legendy z jednych i tych samych ust, że mieszczące się swobodnie w jednej i tej samej głowie [...]. Więc szanować - szaleństwo? Więc czcić - głupotę? Więc kochać - zbrodnię?”18

Trzeźwość ujęcia tego dojmującego i wielce realnego dylematu lokuje Piłsudskiego po stronie Irzykowskiego, nie Schulza. Pogląd autora Wiosny na mechanikę powstawania legend jest diametralnie odmienny i starannie obrany z historycznego konkretu. Porównajmy: „Wielkie

17 Skądinąd trudno oprzeć się myśli, że po akademii żałobnej dyrektor poprosił nauczyciela robót ręcznych na stronę: „Nu, drogi panie kolego, jest pan człowiekiem piszącym, stołecznym literatem - niech pan łaskawie rozważy, czy nie byłoby wskazane, aby opublikował pan, w imieniu całej naszej szkolnej społeczności, coś w rodzaju pożegnania Marszałka. W tym, wie pan, pańskim stylu". Słyszę nawet Iwowski akcent.

18 J. Piłsudski, op. cit., s. 6-7. 
sprawy historii, operacje dziejów toczą się w jakiejś przedsłownej, pozasłownej ciszy dziejowej. Wielka chwila czynu, grom siły i woli, który przeszył ciało narodu, to wszystko, co nazywamy dziś imieniem

ciało

narodu

problem Opatrzności Piłsudskiego, było w swym przebiegu, w swej aktualności nieartykułowane, pozbawione słowa, całe pogrążone w biologii, w żywiole [...]. Przetworzenie duchowe tej "polskiej anabasis», nagły cud wystrzelającego czynu, niespodziana, niewiarygodna dojrzałość dziejowa wcieliła się w człowieka, przybrała najbardziej zagadkową, jednorazową, sfinksową formę potężnej osobistości. W tym fakcie wyraziła się jakby głęboka ironia historii. Wielka chwila dziejowa [...] wynurzyła się wreszcie - gdy przyszła - jakby poza [...] wielką ideologią, jako niezgłębiona siła natury, z całą zagadkowością, nieprzewidzialnością, irracjonalizmem wielkiego indywiduum"19.

Wszystko tu toczy się samo, poza świadomością, a może i wolą ludzką, w podglebiu dziejów. „Intelekt cofa się i kapituluje”20. Gdyż dzieje „dzieją się" o własnych, niezbadanych siłach.

\section{5. w którym zabiera głos Filozofia}

Obiekt legendy - to u Schulza nie jej nosiciel, lecz wcielenie. „Stąd przyszły do mnie siły moje, skąd do Ciebie przyszły Twoje” - sparafrazować można monolog Konrada z Dziadów. Stylizacja ta każe myśleć o Monsalwacie Artura Górskiego. Jednakże Piłsudski, wielkie indywiduum o potężnej witalności, realizuje w oczach pisarza wzorzec nie tyle romantyczny - rządy wcielonego mitu bynajmniej nie przyszły tak, jak to zapowiadali poeci - ile Nietzscheański. Być może dlatego, że wielkości jako takiej sprostać może tylko retoryka woli mocy.

Drugim składnikiem pojmowanej filozoficznie i historiozoficznie kwestii wielkości jest, jak wspominałam, problem Opatrzności. Przez ten pryzmat rozpatrywał swoich bohaterów Carlyle. Co jednak w umyśle świeckim oznaczać może rozważanie wyroków Opatrzności, która jednych naznacza wielkością, a innych pomija? To właśnie zagadnienie stawia autor Sklepów cynamonowych, powracając kilkakrotnie do wizji bohatera z jednej bryły. „Jak może być syn narodu - jego ojcem i twórcą? Czy wola potęgi, nadludzka ambicja, uzurpacja, czy ascetyczna pokora, rezygnacja, całkowita ofiara z siebie? Czy pogarda ludzi i pycha, czy też najczulsza miłość i uwielbienie? Samowystarczalna, zadumana w swej wielkości samotność, czy najwyższa solidarność ze zbiorowością? Rubaszność czy wzniosłość? I czujemy, że te pary antynomiczne według 
jakichś głębszych praw nie znoszą się wzajemnie, lecz sumują w jakąś najwyższą sumę"21. Rozważany poza olśniewającą Schulzowską stylistyką, wywód wskazuje na interesującą procedurę. Jeśli mianowicie przyjmiemy, że problem wielkości należy do zakresu etyki, zostaje on tutaj postawiony na płaszczyźnie estetycznej. Natomiast to, co nazwać można estetyką wielkości, czyli zmysłową komunikację z jej przejawami, rozpatruje Schulz od strony etycznej.

Jeśli szukać źródeł tego stanowiska, które nie jest w nim bynajmniej przejawem pomieszania pojęć, historia myśli odsyła do pojęcia wzniosłości. To zaś w ostatniej ćwierci XVIII wieku, kiedy akurat zaczynało być potrzebne, stworzone zostało na gruncie skontrastowania majestatu z lękiem. Otwarłszy traktat Edmunda Burke’a Dociekania filozoficzne o pochodzeniu naszych idei wzniosłości i piękna, z którym Schulz musiał się zetknąć jako przyszły (acz niedoszły) architekt, znajdziemy tam adekwatne wnioski: „choć w trafnym wyobrażeniu Bóstwa zapewne żaden $\mathrm{z}$ jego atrybutów nie wysuwa się przed inne, to jednak naszą wyobraźnię uderza nade wszystko jego moc. Potrzeba pewnego namysłu i porównania, byśmy uznali jego mądrość, sprawiedliwość i dobroć, ale by olśniła nas jego moc, trzeba tylko, byśmy otworzyli oczy. Gdy zaś kontemplujemy przedmiot tak rozległy [...], kurczymy się w małości własnej natury [...]. A choć wzgląd na inne jego atrybuty może w jakiejś mierze ulżyć naszym obawom, to [...] nie może całkowicie usunąć trwogi, jaką w naturalny sposób budzi siła, której nic się nie może oprzeć"22.

Jeśli w tej perspektywie czytać Powstają legendy, zauważyć można trzy procedury umysłowe, po jakie sięga pisarz, by sprostać swojemu zadaniu. Pierwszym z owych zabiegów jest powszechna semioza. Wielkość kogoś, kto wielkim się staje, potwierdzają każdy szczegół jego biografii, świadectwo czy układ wydarzeń historycznych. Procedura druga nazwana być może extensio. Wedle Burke’a wielkość nie ma charakteru obiektywnego. Podobnie jak pożądanie rodzi się w głowie, a zatem wzrok pożądającego wielkości wypatruje jej i wydobywa z siebie samego składniki tego oczekiwania, obiektywizując je i przerzucając na przedmiot swego uwielbienia. Za trzeci składnik uznać można peryfrazy. Wszelka wypowiedź o wielkości jest $\mathrm{z}$ definicji peryfrastyczna, ponieważ wielkości wprost i merytorycznie wyrazić się nie da. Jest ona zawsze tyleż sugestią, ile faktem. A raczej faktem, który działa jako sugestia, i sugestią, która materializuje się w fakt. Sugestią zbiorową, rzecz

21 Ibidem, s. 22-23.

22 E. Burke, Dociekania filozoficzne o pochodzeniu naszych idei wzniosłości i piękna, przeł. P. Graff, Warszawa 1968, s. 77. 
jasna. I otóż w chwili, gdy wyłania się potrzeba nazwania czyjejś wielkości, okazuje się, że nie można jej istoty uchwycić inaczej, niż w sieć parafraz, a nawet - jak wskazuje Schulz - w zdania antynomiczne. Wtedy rodzi się legenda.

Znaczenie tych trzech procedur wyczytać się daje z przyjętego przez Schulza kryterium rozróżnienia wielkości mniemanej (bądź uzurpowanej) od autentycznej. Pisarz przedstawia tę kwestię, kontrastując dwa le-

dwa płaszcze

w tle Wiosna gendowe płaszcze. Pierwszy z nich - to płaszcz cesarski. Napoleon „ubrał się w historię jak w płaszcz królewski, zrobił z niej tren wspaniały dla swej kariery" 23. Jako artysta Schulz niewątpliwie dostrzegł coś, co chciał skrycie przekazać autor sławnego portretu koronacyjnego Napoleona I, republikanin François Gérard: na swego nosiciela płaszcz ów jest zdecydowanie za duży. Drugi, odmienny i też aż nazbyt obszerny płaszcz, „ciężki marzeniami wieszczów, mglisty rojeniami poetów, obciążony męczeństwem pokoleń”, wlókł za sobą Piłsudski. "Ciągnął za sobą przeszłość, jak płaszcz ogromny na całą Polskę"24. Ale płaszcz ten był niewidzialny.

On to jest ciałe m mitu.

\section{6. w którym dorzuca swoje Stylistyka}

Los zrządził, że z zagadką źródeł legendy Schulz zmierzył się w chwili finalizowania Wiosny. Mógł więc bez trudu sięgnąć do własnych resursów myślowych, ujętych już w jej wymowne, niepowtarzalne na pozór figury stylistyczne. Ma się rozumieć, dowodzi to, że problematyka legendotwórstwa nie była obca ideom konstytutywnym Wiosny (a niekiedy i tekstów wcześniejszych), a ściślej - że w pewnej mierze stanowi ich refleks, nadliczbowe, nieprzewidziane odgałęzienie. Należałoby więc może przeformułować te zdania. Pisząc o micie Marszałka, Schulz m u s i a ł sięgnąć po intuicje i przemyślenia Wiosny, jej nadliczbowym zaś, nieprzewidzianym odgałęzieniem stał się Piłsudski.

By to wskazać, nie trzeba jednak zgłębiać „aspiracyj, bezgranicznych pretensyj, wezbranych i nie objętych ambicyj" wymuszonych na rzeczywistości intrygą Wiosny. Wystarczy kilka paralel.

Ideowym punktem wyjścia tej opowieści jest wiek XIX, uosobiony w postaci cesarza Franciszka Józefa. „Jego żywiołem był świat ujęty w regulaminy prozy, w pragmatykę nudy. Duch kancelaryj i cyrkułów był jego duchem. [...] On to wymyślił w pewnego rodzaju przewidującej dobrotliwości c. k. loterię dla ludu, senniki egipskie, kalendarze 
ilustrowane oraz c. k. tabak-trafiki"25. Studium Powstaja legendy kontynuuje ten obraz: „Ludzkość odetchnęła z ulgą. Poprzysięgła sobie nie rodzić więcej wielkich ludzi. Zaprzeczyła ich istnieniu. Nastała restauracja małości. [...] Podzielono cały obszar życia, rozkawałkowano, poddano kontroli. Proklamowano niemożliwość wielkości [...]. Wysunięto nieosobowy proces dziejowy, cyfry i statystykę"26. Łatwo dostrzec, że jest to ten sam wywód.

Jak wiemy, odmalowany powyżej stan rzeczy zdolny jest zrodzić oczekiwanie. Oto niebawem nadejdzie wielkość, ucieleśniona w kimś i w wypadkach; pora odczytać ich kształt w znakach zapowiednich. Takiej profecji oddaje się, patrząc w niebo, narrator Wiosny, przeczuwając, że w pewnej mierze sam projektuje to, co się zbliża: „Niebo zamknęło się, zatarasowało, wzbierając coraz ciemniejszą stalową burzą, i milczy nisko skłębione. [...] Coś chce się sfermentować ze zgęszczonego szumu tych dni spochmurniałych - coś rewelacyjnego, coś ponad wszelką miarę ogromnego. Próbuję i przymierzam, jakie zdarzenie mogłoby sprostać tej negatywnej sumie oczekiwania, która zbiera się w ogromny ładunek ujemnej elektryczności [...]. Gdzieś już rośnie i potężnieje to, na co w całej naturze naszej gotuje się ta zaklęsłość" 27. Zadanie to w omówieniu Wolności tragicznej Wierzyńskiego przypada poecie: „Patrzeć w to wielkie na całe niebo oblicze mitu i czytać zeń i wywróżyć i wymajaczyć, co się w nim marzy bezimiennie! Wypruć go ostrożnie z łona chmury, schwytać w sidła słów, co przelewało się w tych potencjalnych ładunkach, w tej niezwiązanej, błędnej elektryczności, a zarazem nie przerywać pępowiny mitu [...]. Bo dno mitu musi komunikować z niezrozumiałym i przedsłownym, jeśli ma pozostać żywe"28. Trudno orzec, co w tych bliskich sobie obrazach prymarne: nadciągający mrok czy zapowiedź gromu.

Dziwny traf sprawil, że autor Wiosny zmierzył się z autorem dawnej, lecz pamiętnej książki poetyckiej Wiosna $i$ wino. Mając ją w pamięci, Schulz przywołuje młodość, gotową przed laty na przyjęcie legendy - tak jak z jego własnej Wiosny wysnuła się pewna dynastyczna legenda. Leży u jej początku wiosna niepojmowalna, „pusta, wklęsła i zatchnięta. Nie wiedząc o tym, uciszała się w sobie, milkła, cofała się w głąb - robiła miejsce $[. .$.$] - zdziwiona naga forma dla przyjęcia niewiadomej treści”29.$ Także oczekująca na legendę młodość poety: „Była to wówczas jeszcze 
bohater jako manekin mglista magma mitu, pełna świtania i wiosny, zawikłana we własnym rozkwicie, zgubiona w swej gęstwinie, jeszcze nie czytająca w sobie jasno i pełna szczęśliwych nieporozumień, roztopiona we własnym rozwichrzeniu, we własnej uniwersalnej ekspansji”30. Obie wizje pochodzą najwyraźniej ze wspólnego korzenia odwiecznych opowieści.

Można tę listę ciągnąć, lecz sięgnę po inny przykład. Jednym z najgłębiej heretyckich założeń Traktatu o manekinach jest prowokacyjna rezygnacja ojca z doskonałości. Stwarzając, nie zamierza naśladować Demiurga, pragnie go imitować, a więc parodiować: „Nasze kreatury nie będą bohaterami romansów w wielu tomach. [...] Często dla jednego gestu, dla jednego słowa podejmiemy się trudu powołania ich do życia na tę jedną chwilę. [...] Naszą ambicję pokładać będziemy w tej dumnej dewizie: dla każdego gestu inny aktor"31. Podobnie parodystycznie obchodzi się w uwagach o Wolności tragicznej historia z tymi, których ominęła rola wybrańców: „Jakże wielu zbytecznych przelicza ona obojętnie [...], zużywa prędko i pobieżnie, tyle w nich trwania, ile tchu w tym jednym słowie, które zdołali odkrzyknąć na jej pytanie. Bo stać ich było zaledwie na jedno słowo, całego życia ich starczyło zaledwie na jedną głoskę"32. Duch dziejów szafuje tu okrucieństwem nieprawej demiurgii.

Co z tych zbieżności wynika dla sensu mitu Marszałka? Umieszczając go w kręgu własnej opowieści, poddając prawom swej najosobistszej pisarskiej wyobraźni, Schulz zarazem amplifikował Piłsudskiego, jak też go sobie podporządkował. Znalazł dlań miejsce w świecie fantasmagorii, wyprowadzil, jak inne własne twory, z mrocznych podglebi opowieści, poddał regułom poetyckiej ekspansji. Hołd Piłsudskiemu oddał, czyniąc go częścią siebie - i opisał tak, jak zwykł przedstawiać swe postacie. Jak inni formalnym rytuałom kultu, sprawiedliwości boskiej, osądowi Historii, tak on powierzył go opiece Wyobraźni. 